\title{
Smiljana Komar
}

\section{THE INTERFACE BETWEEN THE PRODUCTION AND PERCEPTION OF INTONATION PHRASE BOUNDARIES AND NUCLEAR SYLLABLES}

\begin{abstract}
Tonality and tonicity are used in the organization of information in speech. English heavily relies on tonality and tonicity to focus on particular parts of the information structure, whereas Slovene achieves that by means of shifting the word order. In order to find the relationship between the production and perception of intonation phrase (IP) boundaries and nuclear syllables, I carried out a test with students of English who were divided into two groups. Group A was asked to read a text and divide it into IP's and to underline the nuclear syllables, while Group B listened to the same text read by a native speaker of English and marked the IP boundaries and nuclear syllables as they perceived them. The results show that the division into IP's is generally not problematic. Group $A$ has found the location of the nuclear syllable most problematic, whereas Group $B$ has shown generally better results both in tonality and tonicity. Most problematic have been those IP's where the English speaker has used the fall-rise tone: the students have decided for either one or even two nuclear syllables in one IP.
\end{abstract}

Key words: sentence intonation, sentence nucleus, tonicity (linguistics), English, Slovene

\section{INTRODUCTION}

\subsection{Tonality}

Tonality is a system which divides spoken discourse into smaller units known as intonation phrases (IP) (Wells, 2006), also referred to as word groups (O'Connor \& Arnold, 1973), tone groups (Halliday, 1967), tone units (Brazil, 1997) or intonation units (Tench, 1996). It is a system which largely reflects and depends on the grammatical structure of a language, but is also very much conditioned by the speaker's perception of the context of interaction. Essentially, each IP contains one piece of information as the speaker perceives it. Halliday (1967: 18-19) observes that the division into IP's often follows the division into sentences and clauses and refers to it as neutral tonality. He also observes cases when one clause is divided into two or more IP's, as well as cases when two clauses are joined into one IP. He refers to such instances as marked tonality. The important thing about tonality is that it signals to the hearer the syntactic as well as the information structure of the sentence. 
In English, intonation breaks, which indicate the divisions between individual IP's, are often used to disambiguate a potentially ambiguous syntactic or information structure. In spite of the fact that speakers can insert intonation breaks almost anywhere they want in order to make their message as clear as possible, there are nevertheless some strong tendencies exerted by grammar over tonality. In English some components of syntactic structure are more likely than others to be made into separate IP's. Wells (2006: 195-206) recognizes seven of them: (1) vocatives, (2) adverbials, (3) defining and non-defining relative clauses, (4) lists and parallel structures, (5) tag questions, (6) heavy noun phrases and (7) topics.

Similarly to English, tonality in Slovene reflects and depends on the grammatical structure of the language. Toporišič (1984: 438-445) discerns that not all breaks are equally long and that their length depends on the syntactic structures between which the breaks are made. He recognizes three typical places for intonation breaks. These are: (1) at the end of sentences, (2) between different types of clauses, and (3) before appositions. The longest intonation break is between sentences and it varies depending on the type of sentence, as well as on the reader's artistic interpretation of the message. The latter is often the reason why two sentences are read as one, but even more frequently, why one sentence is divided into more IP's. The second most frequent place for intonation breaks is between different types of clauses. In subordination, the intonation breaks are usually made before the subordinate post-modifying clauses. In coordinated clauses with the conjunctions in and ter the intonation breaks are less frequent; in other types of coordination the intonation breaks are more typical. When elements with identical reference (i.e. apposition) or additional information (i.e. non-defining) are placed next to each other, they are treated as separate IP's. If they are said as one IP, they provide defining information about the element with which they occur.

\subsection{Tonicity}

Tonicity is a system by means of which speakers decide on the focus of information. Thus, in every IP speakers have to select one word which they find most important for the meaning, i.e. the focus of information. The stressed syllable within that word becomes the nucleus of that particular IP and bears the tone.

Most important for the information structure of the message is the organization of information in terms of old, or given, and new information. Halliday (1967) points out that the normal distribution of information in an IP is to present the given or old information first and the new information last. If the entire IP conveys new information, the nucleus indicates its end; hence it is placed on the last lexical item in the IP. In other words, the information of the whole IP is in focus. This is broad focus. The location of the nucleus changes with the development of the conversation. The context influences the speaker's choice as to which part of the message will be presented as new information. If the last lexical item conveys given or old information, then the nucleus is moved to the left and is located on that word 
which conveys new information. This is referred to as narrow focus. A particular kind of narrow focus is contrastive focus. As the name suggests, the speaker makes an explicit or implicit contrast between two pieces of information. In the case of explicit contrastive focus the two lexical items expressing contrasting pieces of information receive nuclei. In the case of implicit contrastive focus, the hearer has to infer from the context of interaction the contrasted piece of information. The important thing about focus is that it is dynamic, meaning that speakers constantly shift the place of the nucleus around, though always in agreement with the development of the interaction and their perception of given, implied and new information

Although Toporišič (1984) does not explicitly make a distinction between broad and narrow focus, it can be concluded that the Slovene language uses similar principles as the English language when highlighting important pieces of information. However, due to the difference and flexibility in word order in Slovene, a distinction is made between neutral and marked word order, as well as between the broad and narrow focus.

Toporišič (1984: 448) claims that there is a general principle according to which in unmarked contexts of interaction the nucleus occurs on the last accented syllable in an IP, as in example (1).

(1) Našo barako je zamedlo. (engl. Our hut was snowed in.)

The exception to this rule are wh-questions, where the nucleus is located on the wh-word, as in example (2).

(2) Kdo je ta človek? (engl. Who is this man?)

On the basis of a more detailed analysis, Šuštaršič (2005: 33-44) recognizes three other cases of broad focus in Slovene. These include the negative particle $n i$ (engl. not), indefinite pronouns and adverbs such as nikoli (engl. never), vedno (engl. always), nič (engl. nothing), and comparative and superlative bolj (engl. more), najbolj (engl. most) and their synonyms (examples 3 through 8).

(3) To ni zanimivo. (engl. This is not intresting.)

(4) Nikoli ne je čebule. (engl. He never eats onion.)

(5) Vedno govori resnico. (engl. He always tells the truth.)

(6) Nič ga ne more presenetiti. (engl. Nothing can ever surprise him.)

(7) Tone je bolj priden kot Janez. (engl. Tony is more diligent than Lohn.)

(8) To je bila najbolj nesramna pripomba. (engl. This was the most impertinent remark.)

Komar (2008: 48-9) observes that in the Slovene language a kind of implicit narrow focus is often achieved through the use of the particle $p a$, which also 
influences the position of the nucleus. Example (9) is a straightforward question that asks the hearer about the identity of a particular person; the nucleus is on the question word $k d o$ (engl. who), and the focus is broad. In example (10) the verb is pre-modified by the particle $p a$, which makes an implicit reference to the context of interaction: perhaps the speaker is interrupted by an unexpected visitor ringing at the door and wants to know that person's identity. In this case the focus is narrow and the nucleus changes its location from the question word to the demonstrative to (engl. this):

(9) Kdo je to? (engl. Who's that?) (broad focus)

(10) Kdo pa je to?? (engl. And who is that?) (implicit narrow focus)

Finally, there is another stylistic specialty in Slovene which allows for IP's to have two nuclei. They can occur either in longer nominal phrases which often make IP's of their own, or on particular grammatical items in clauses. They always consist of a fall + rise and have particular communicative functions (see Komar, 1999).

\section{METHODOLOGY AND SUBJECTS}

Although the students of English are taught about the main tonality and tonicity differences between the languages and are exposed to intense ear-training the purpose of which is to improve the recognition of tones and whole tunes, it remains to be found out how aware they are of them when producing and perceiving spontaneous speech. It is my assumption that the influence of the mother tongue upon production is stronger than upon perception. With that in mind, I carried out a production and perception test with the $3^{\text {rd }}$ and $4^{\text {th }}$ year students of English. Group A (30 students) was asked to read a text and divide it into IP's and to underline the nuclear syllables, while Group B (30 students) listened to the same text read by a native speaker of English and marked the IP boundaries and nuclear syllables as they perceived them. I chose a section from Helen Fielding's novel Bridget Jones: The Edge of Reason where Bridget Jones interviews the actor Colin Firth.

\section{RESULTS}

\subsection{Production of tonality and tonicity}

The results have shown that the division into IP's is generally not problematic. Group A has found the use of comma in English confusing with its use in Slovene where a comma is usually an indicator of a new IP. The use of comma in English follows different principles than in Slovene where it has a strictly grammatical function of separating clauses. In English commas are used also before or after certain discourse markers (DM) which may have the form of words, phrases or even clauses (examples 11 and 12). Although there is a lot of variation regarding the 
tonality of DM's in English, group A strictly followed the Slovene principle for the use of comma and treated DM's as separate IP's, as in examples 11a, and 12a:

(11) Anyway, is OK. ||

(11a) Anyway, | is OK. ||

(12) Why do you think that, though?

(12a) Why do you think that, | though?

More problematic for group A has been the location of the nuclear syllable where the differences between Slovene and English are most evident. Generally, we can distinguish between three types of errors in N-placement:

a) those which are the result of the influence of the Slovene language;

b) those which are the result of wrong lexical stress (i.e. phrasal verbs and compounds)

c) absence of $\mathrm{N}$ on emphatic auxiliaries.

Under the influence of the mother tongue, group $\mathrm{A}$ has decided to place $\mathrm{N}$ on negative words (example 13a) comparative or superlative adverbs (example 14a) instead of on the last lexical items (examples 13 and 14):

(13) Mr. Darcy's not an Arsenal supporter.

(13a) Mr. Darcy's not an Arsenal supporter.

(14) And I don't think they would be very appealing.

(14a) And I don't think they would be very appealing.

A great number of errors in $\mathrm{N}$-placement are the result of students not knowing the lexical stress pattern of phrasal verbs (example 15) and compounds (example 16). They have wrongly put the $\mathrm{N}$ on the lexical verb (example 15a) thus producing a contrastive focus, or on the first element of a late-stressed compound (example 16a):

(15) Did you have to take the wet shirt off?

(15a) Did you have to take the wet shirt off?

(16) You know in the BBC Pride and Prejudice?

(16a) You know in the BBC Pride and Prejudice?

In the text the speakers use a lot of emphatic auxiliary verbs which they realise either as pre-nuclear accented syllables (example 17) or nuclear syllables (example 18). A large number of students have failed to do so and put nuclei on the lexical verbs (examples 17a and 18a):

(17) I "did speculate what his politics might be

(17a) I did speculate what his politics might be 
(18) I do think I'm not like Mr. Darcy

(18a) I do think I'm not like Mr. Darcy

\subsection{Perception of tonality and tonicity}

Group B has shown better results both in tonality and tonicity. Most problematic have been those IP's which consisted of the nuclear and pre-nuclear segment (example 19). The students have divided such IP's into two, each having one $\mathrm{N}$ syllable, as in example 19a:

(19) "Jones meets Darcy. || "Jones meets Blair. || "Jones meets Marcos | except dead.

(19a) Jones | meets Darcy. || Jones | meets Blair. || Jones | meets Marcos | except dead.

A similar error has occurred with those IP's where the English speaker has used the fall-rise tone which has been followed by a longer tail (example 20). Due to the fact that the fall-rise tone is then pronounced so that the falling part is realised on the $\mathrm{N}$ syllable, while the rising part is carried out throughout the tail, the students have decided for two IP's, as in example 20a:

(20) $\searrow \nearrow$ All top journalists have deadline crises.

(20a) \. All top journalists $\mid$ have deadline $\boldsymbol{}^{\boldsymbol{c}}$ crises.

The results have also shown that the students in group B had problems with the rising tones when they are followed by a tail (example 21). They have placed the nucleus on the last stressed syllable of the tail which is highest in pitch and not on the lowest syllable which marks the beginning of the rising tone, as in example 21a:

(21) $\mathrm{Ex}^{\lambda}$ cuse me.

(21a) Excuse $\lambda_{\text {me. }}$

\section{CONCLUSION}

The purpose of the production and perception tests was to verify the initial assumption that the influence of the mother tongue on the production of speech is stronger than on its perception. The results have shown that the division of speech into intonation phrases is fairly unproblematic from the point of view of production as well as perception. The only confusing element is the use of comma which in English follows different principles than in Slovene and is not always a marker of an IP boundary. This means that the Slovene speakers of English have to learn when to observe a comma as an IP boundary and when to ignore it as such. 
Production of nuclear syllables in IP's is more problematic and remains to be heavily influenced by the principles of the mother tongue. The results have confirmed the assumption that speakers subconsciously put nuclei on the same words as they would in Slovene. When it comes to the perception of nuclear syllables, the most problematic remain those IP's which contain the fall-rise tones. These are systematically perceived as having two nuclear syllables which means that the students can hear two pitch movements but cannot recognize them as one tone. This may to some extent be due to the influence of the mother tongue where the socalled split fall-rise is not unusual. The other serious perception problem is related to the rising tones where the students hear the end of the tone as the nuclear syllable and not its beginning. On the basis of the obtained results, I can conclude that the interface between the production and the perception of IP boundaries and nuclear syllables is minimal. Systematic ear-training of different tones can only to some extent improve their perception, but does not influence their production in reading or in spontaneous speech.

\section{REFERENCES}

Brazil, D. (1997). The communicative value of intonation in English. Cambridge: Cambridge University Press.

Fielding, H. (1999). Bridget Jones: The edge of reason. 3 Audio CDs. London: MacMillan Audio Books.

Halliday, M. A. K. (1967). Intonation and grammar in British English. The Hague: Mouton.

Komar, S. (1999). The fall-rise: A new tone in the Slovene sentence intonation. Govor 14, 2, 139-48.

Komar, S. (2008). Communicative functions of intonation: English-Slovene contrastive analysis. Ljubljana: Znanstveni inštitut Filozofske fakultete.

O'Connor, J. D., Arnold, G. F. (1973). Intonation in Colloquial English. $2^{\text {nd }}$ edn. London: Longman.

Šuštaršič, R. (2005). English-Slovene contrastive phonetic and phonemic analysis and its application in teaching English phonetics and phonology. Ljubljana: Znanstveni inštitut Filozofske fakultete.

Tench, P. (1996). The intonation systems of English. London: Cassel.

Toporišič, J. (1984). Slovenska slovnica. Maribor: Založba Obzorja.

Wells, J. C. (2006). English intonation. Cambridge: Cambridge University Press. 


\section{ODNOS IZMEĐU PROIZVODNJE I PERCEPCIJE GRANICA INTONACIJSKIH CJELINA I NAGLAŠENIH SLOGOVA}

\section{Sažetak}

Tonalnost $i$ toničnost koriste se u organizaciji informacije u govoru. Engleski se jezik črrsto oslanja na tonalnost $i$ toničnost kako bi naglasio pojedine dijelove informacijske strukture, dok slovenski to postiže promjenom reda riječi. Da bi se pronašla veza između produkcije i percepcije granica intonacijske jedinice (IJ) i jezgrenog sloga, provedeno je ispitivanje sa studentima engleskog koji su podijeljeni u dvije grupe. Grupa A zamoljena je da pročita tekst, podijeli ga na IJ $i$ označi jezgreni slog, a ispitanici u grupi B slušali su isti tekst, koji je pročitao izvorni govornik engleskog jezika, i trebali su označiti kako su percipirali granice IJ-a i jezgreni slog. Rezultati pokazuju da podjela na IJ općenito nije problematična. Grupi A najteže je bilo odrediti mjesto jezgrenog sloga, a grupa B imala je općenito bolje rezultate vezane uz tonalnost i toničnost. Najproblematičnije su bile one IJ u kojima je engleski govornik imao silazno-uzlaznu intonaciju: studenti su se odlučili za jedan ili dva jezgrena sloga unutar jedne IJ.

Ključne riječi: intonacija rečenice, jezgra rečenice, tonalnost (lingvistika), engleski jezik, slovenski jezik 